\title{
13. DIATOM BIOSTRATIGRAPHY OF SITES 495, 496, AND 497, DEEP SEA DRILLING PROJECT LEG $67^{1}$
}

\author{
Howard E. Harper, Jr., Arco Oil and Gas Co., Dallas, Texas \\ Jonathan Rider, Consultant, Loomis, California \\ and \\ William H. Abbott, Mobil Exploration and Producing Services, Inc., Dallas, Texas
}

\section{INTRODUCTION}

Samples from Leg 67 sites were taken by shipboard personnel for this shore-based study of diatom biostratigraphy. Data from only three sites are presented in this paper because of the authors' time restrictions. Each author studied the samples from one site: Site $495,12^{\circ}$ $29.78^{\prime} \mathrm{N}, 91^{\circ} 2.26^{\prime} \mathrm{W}$ (Howard Harper, Jr.), Site 496, $13^{\circ} 03.82^{\prime} \mathrm{N}, 90^{\circ} 47.71^{\prime} \mathrm{W}$ (William Abbott), and Site $497,12^{\circ} 59.23^{\prime} \mathrm{N}, 90^{\circ} 49.68^{\prime} \mathrm{W}$ (Jonathan Rider).

\section{DIATOM ZONATION}

The studies of Burckle $(1972,1977$, in press) are the most important references for diatom biostratigraphy in the tropical Pacific. The datum levels and zonation published by Burckle are cited in this study and used for correlation and age assignments (Fig. 1). The taxa referenced in this report are listed in Table 1.

\section{Site 495}

Site 495 is located on the oceanic plate west of the Middle America Trench (Fig. 2). Well-preserved diatoms are present in samples from Cores 3 to 19. Diatoms in Cores 20 to 23 are poorly preserved, when present, and several samples were barren. The occurrence of key stratigraphic taxa is shown in Table 2 and Figure 3 . The diatom zonation developed by Burckle $(1972,1977)$ is easily recognized in the section from Core 3 to Core 19 . An unconformity is present between Samples 495-18-1, 20-21 cm and 495-19-1, 20-21 cm. The sample from Core 18 contains Hemidiscus cuneiformis and Nitzschia miocenica and is no older than Paleomagnetic Epoch 7. The sample from Core 19 contains Denticulopsis hustedtii and Coscinodiscus paleaceus, lacks any $H$. cuneiformis, and is no younger than Paleomagnetic Epoch 12 (Fig. 1). The section between Cores 19 and 24 is barren of any age diagnostic diatoms. Poorly preserved diatoms occur in Core 24, and preservation is good in samples from Cores 26 through 31,35 , and 36 . The assemblage from these samples contains several middle to early Miocene diatoms (Annellus californicus, Raphidodiscus marylandicus, Coscinodiscus lewisianus, Borgorovia veniamini, Craspedodiscus coscinodiscus), but also pres-

\footnotetext{
${ }^{1}$ Aubouin, J., von Huene, R., et al., Init. Repts, DSDP, 67: Washington (U.S. Govt. Printing Office).
}

ent are several forms that Jousé (1974) restricts to the Oligocene (Coscinodiscus oligocenicus, Cestodiscus ssp.). Data from the other microfossil groups shown in Figure 3 agree with an early and middle Miocene age assignment for these sediments (P. Thompson, personal communication, 1981).

\section{Site 496}

Site 496 is located on the continental slope of the Middle America Trench (Fig. 2). It is the most landward site of those examined in this report. Diatoms are wellpreserved in Cores 1 to 28 and poorly preserved in Cores 29 to 40 . Several of Burckle's zones are recognized (Table 3), but there are three noticeable uncomformities in the sequence. The first occurs between the Pleistocene and the Pliocene. The base of the Pleistocene is located below the base of Pseudoeunotia doliolus in Core 25 . Sample 496-26-1, 20-21 cm contains Nitzschia jouseae and Thalassiosira convexa and probably is in the $N$. jouseae Zone (Pliocene), because Rhizosolenia praebergonii is not present. This means the $R$. praebergonii Zone is missing or is very thin and falls between the studied samples. The second unconformity occurs between Samples 496-26-1, 20-21 cm and 496-27-2, 20-21 $\mathrm{cm}$. The sample in Core 26 is in the $N$. jouseae Zone; Core 27 contains $N$. miocenica and $T$. convexa and is in the $T$. convexa Zone (upper Miocene). The third unconformity occurs between Core 28 (still within the $T$. convexa Zone) and Cores 30 to 40, which contain Craspedodiscus coscinodiscus, Synedra jouseana, and sporadic occurrences of several other middle Miocene diatoms.

The diatom biostratigraphy of Hole 496 indicates a thick Pleistocene section overlying thin units of Pliocene, upper Miocene, and middle Miocene, each bounded by unconformities.

\section{Site 497}

Site 497 is located on the landward side of the Trench slope (Fig. 2). The stratigraphic order of Pliocene and Pleistocene diatom datum levels at Site 497 generally supports the findings of Burckle $(1972,1977)$ and Barron (1980) in their investigations of diatom floras in equatorial Pacific sediments (Fig. 1). The distribution of datum levels at Site 497 indicates episodic deposition with minor discontinuities, especially in the upper part of the section where the high abundance of nonmarine diatoms suggests a change in the depositional processes. 


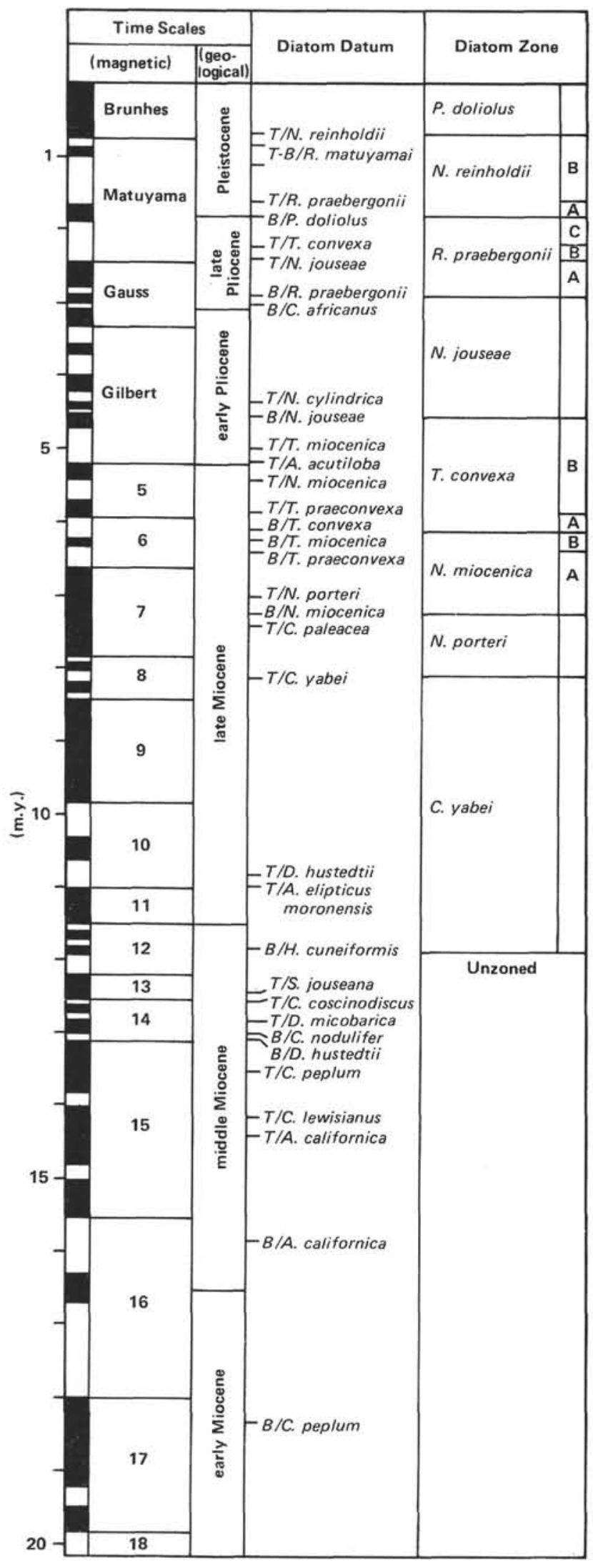

Figure 1. Eastern equatorial Pacific diatom chronology (data from Burckle, 1972, 1977; $T=$ top, $B=$ base; $=$ normal polarity, $\square$ $=$ reversal polarity; $\mathrm{A}, \mathrm{B}$, and $\mathrm{C}=$ diatom subzones).
Many of the uppermost cores (generally from Samples 497-29-2, 20-21 cm to 497-1-2, 20-21 cm) contain well-preserved diatoms mixed with partially dissolved and fragmented specimens. Generally, below Core 29, increasing dissolution of the diatom valves occurs, with the exception of Samples 497-33-1, 20-21 cm and 49734-2, 49-50 cm, which contain well-preserved floras. Sample 497-30-2, 20-21 cm contains very sparse diatoms; Sample 497-39-2, 20-21 cm is barren of diatoms.

The occurrences of stratigraphically significant diatom taxa are shown in Table 4 . The youngest four zones of Burckle (1977) are identified in Hole 497, representing Pleistocene to middle Pliocene sediments. The Pliocene/Pleistocene boundary is placed between Cores 24 and 25, using the base of Pseudoeunotia doliolus. Within the Pleistocene section (Cores 1-24), the tops of Nitzschia reinholdii, $N$. fossilis, and Mesocena quadrangula all fall between Samples 497-15-2, 20-21 cm and 497-14$2,20-21 \mathrm{~cm}$. Burckle (1977) and Barron (1980) find the top of $N$. reinholdii above those of $N$. fossilis and $M$. quadrangula. Their co-occurrence in Holes 497 and 495 may be the result of small hiatuses or the size of the sampling interval. However, in Hole 496, M. quadrangula occurs above the youngest occurrence of $N$. reinholdii, and $N$. fossilis was not found. This suggests that the youngest occurrences of these three taxa are affected by environmental factors in this area.

Within the $N$. reinholdii Zone (Cores 15-24) there are two significant datum levels. The youngest is the occurrence of Rhizosolenia matuyamai in Sample 497-17-2, $20-21 \mathrm{~cm}$. The single occurrence represents the entire range of this short-lived taxa, which has been dated as 0.9 to $1.0 \mathrm{~m}$.y old (see Fig. 1). The other datum level is the top of $R$. praebergonii, which is correlated to just above the Olduvai Event, near the Pliocene/Pleistocene boundary.

Below the base of $P$. doliolus, in Sample 497-25-2, $20-21 \mathrm{~cm}$, is the top of Thalassiosira convexa, indicating deposition in the late Pliocene and establishing the $R$. praebergonii Zone. Just below this datum level is the top of $N$. jouseae, which is correlated to the middle of the late Pliocene. The base of $R$. praebergonii identifies the top of the $N$. jouseae Zone and occurs between Samples $497-27-2,20-21 \mathrm{~cm}$ and $497-28-2,20-21 \mathrm{~cm}$, along with the base of Coscinodiscus africanus. These two datum levels are correlated to just above the upper/lower Pliocene boundary. No other datum levels are recognized from Core 28 to the bottom of the hole (Core 42). It is possible that the base of $N$. jouseae occurs in Core 41 , but poor preservation and sporadic occurrences of $N$. jouseae higher in the hole make this interpretation tentative. The samples from Cores 28 to 42 were deposited in the early Pliocene, and no later than the middle early Pliocene.

\section{ACKNOWLEDGMENTS}

We would like to thank J. Bennett and F. Michael for reviewing the manuscript and G. Adian for typing it. We also appreciate the helpful discussions with J. Barron and L. Burckle. 
Table 1. Diatom and silicoflagellate taxa referenced in this report.

\begin{tabular}{|c|c|}
\hline Actinocyclus ellipticus Grunow & Nitzschia cylindrica Burckle \\
\hline Actinocyclus ellipticus javanicus Reinhold & Nitzschia fossilis (Frenguelli) \\
\hline Actinocyclus ingens Rattray & Nitzschia jouseae Burckle \\
\hline Annellus californicus Tempere & Nitzschia marina Grunow \\
\hline Asterolampra acutiloba Forti & Nitzschia miocenica Burckle \\
\hline Borgorovia praepaleacea (Schrader) & Nitzschia porteri sensu Burckle \\
\hline B. tatsunokuchiensis (Koizumi) & Nitzschia reinholdii Kanaya \\
\hline B. veniamini Jousé & Pseudoeunotia doliolus (Wallich) \\
\hline Coscinodiscus africanus Janisch & Raphidodiscus marylandicus \\
\hline Coscinodiscus lewisianus Greville & Rhaphoneis parilis Hanna \\
\hline Coscinodiscus marginatus Ehrenberg & Rhizosolenia bergonii Peragallo \\
\hline Coscinodiscus nodulifer Schmidt & Rhizosolenia matuyamai Burckle \\
\hline Coscinodiscus oligocenicus Jousé & Rhizosolenia praebergonii Muchina \\
\hline Coscinodiscus paleaceus Grunow & Rhizosolenia praebergonii robusta Burckle and Trainer \\
\hline Coscinodiscus symbolophorus Grunow & Roperia tesselata (Roper) \\
\hline Coscinodiscus temperei Brun & Roperia tesselata var, ovata Heiden and Kolbe \\
\hline Coscinodiscus yabei Kanaya & Rouxia naviculoides Schrader \\
\hline Craspedodiscus coscinodiscus Ehrenberg & Synedra jouseana Sheshukova-Poretzkaya \\
\hline Denticulopsis hustedtii (Simonsen and Kanaya) & Thalassiosira convexa Muchina \\
\hline Denticulopsis nicobarica (Grunow) & Thalassiosira leptopus elliptica (Kolbe) \\
\hline Hemidiscus cuneiformis Wall & Thalassiosira miocenica Schrader \\
\hline Mesocena quadrangula Ehrenberg & Thalassiosira oestrupii (Ostenfeld) \\
\hline
\end{tabular}

\section{REFERENCES}

Abbott, W., 1978. Correlation and zonation of Miocene strata along the Atlantic Margin of North America using diatoms and silicoflagellates. Mar. Micropaleontol., 3:15-34.

Barron, J., 1980. Upper Pliocene and Quaternary diatom biostratigraphy of Deep Sea Drilling Project Leg 54, Tropical eastern Pacific. In Rosendahl, B. R., Hekinian, R., et al., Init. Repts. DSDP, 54: Washington (U.S. Govt. Printing Office), 455-485.
Burckle, L., 1972. Late Cenozoic planktonic diatom zones from the eastern equatorial Pacific. Nova Hedwigia Beih., 39:217-246.

1977. Pliocene and Pleistocene diatom datum levels from the Equatorial Pacific. Quat. Res., 7:330-340.

, in press. Early Miocene to Pliocene diatom datum leveis for the Equatorial Pacific. Proc. Indonesian Neogene Symposium.

Jousé, A., 1974. Diatoms in The Oligocene-Miocene biostratigraphic zones of the tropical areas of the Pacific Ocean. Nova Hedwigia Beih., 45:333-357. 


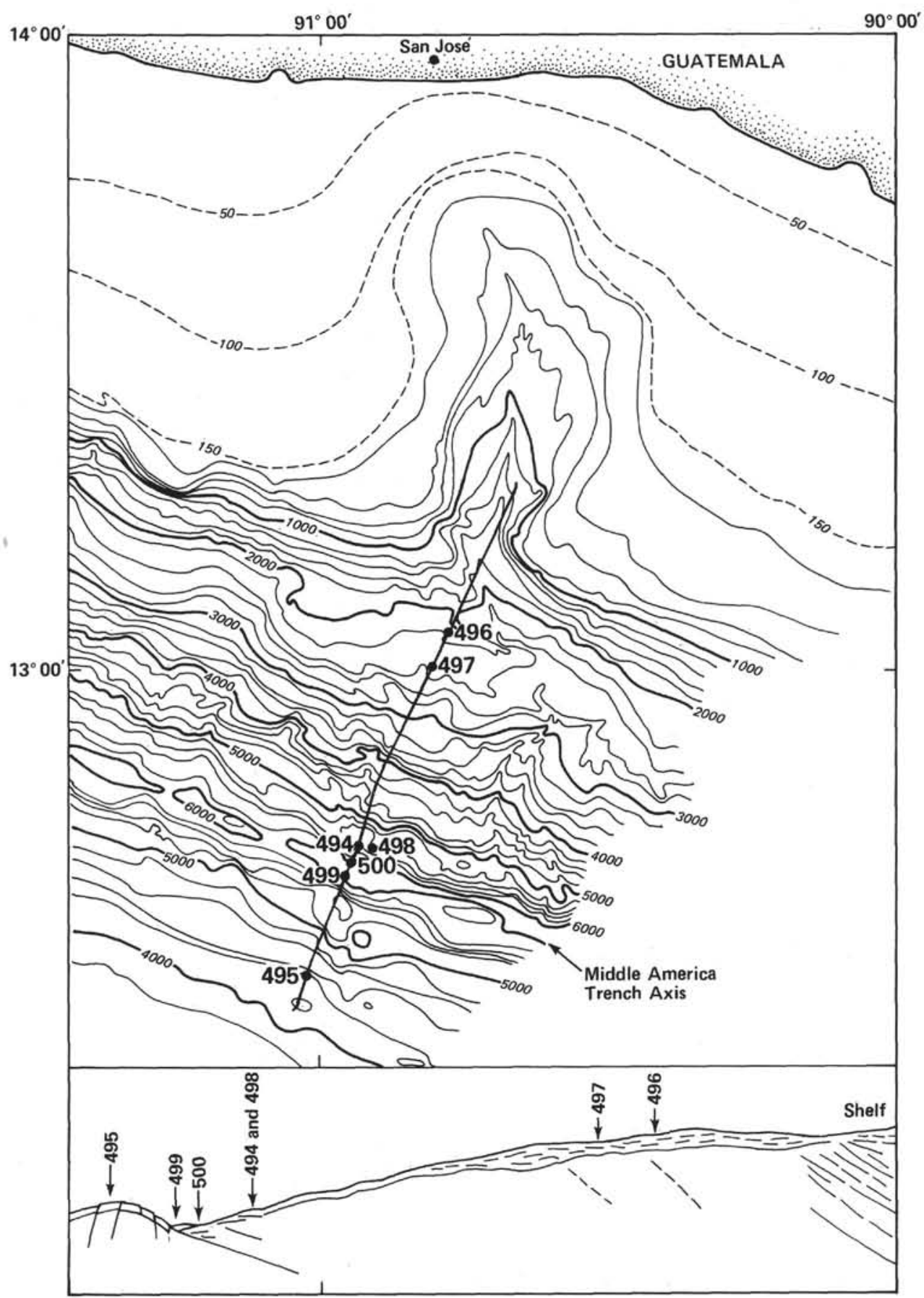

Figure 2. Locations of DSDP sites. 
Table 2. Diatom occurrence chart and zonal and age assignments for the upper part of Hole 495 .

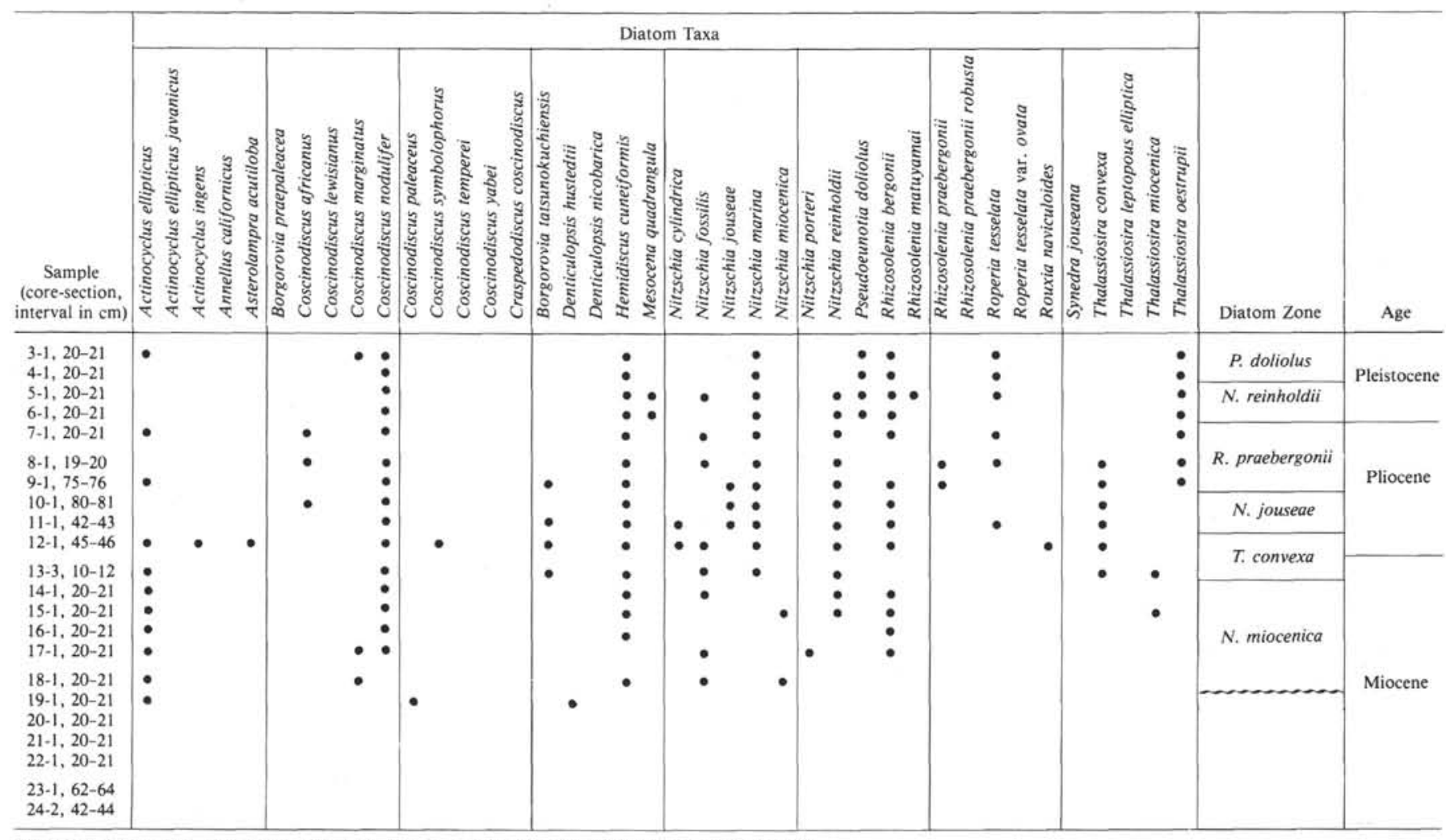

Note: $\bullet$ indicates presence in sample. The occurrence of key stratigraphic taxa is also shown in Figure 3. 


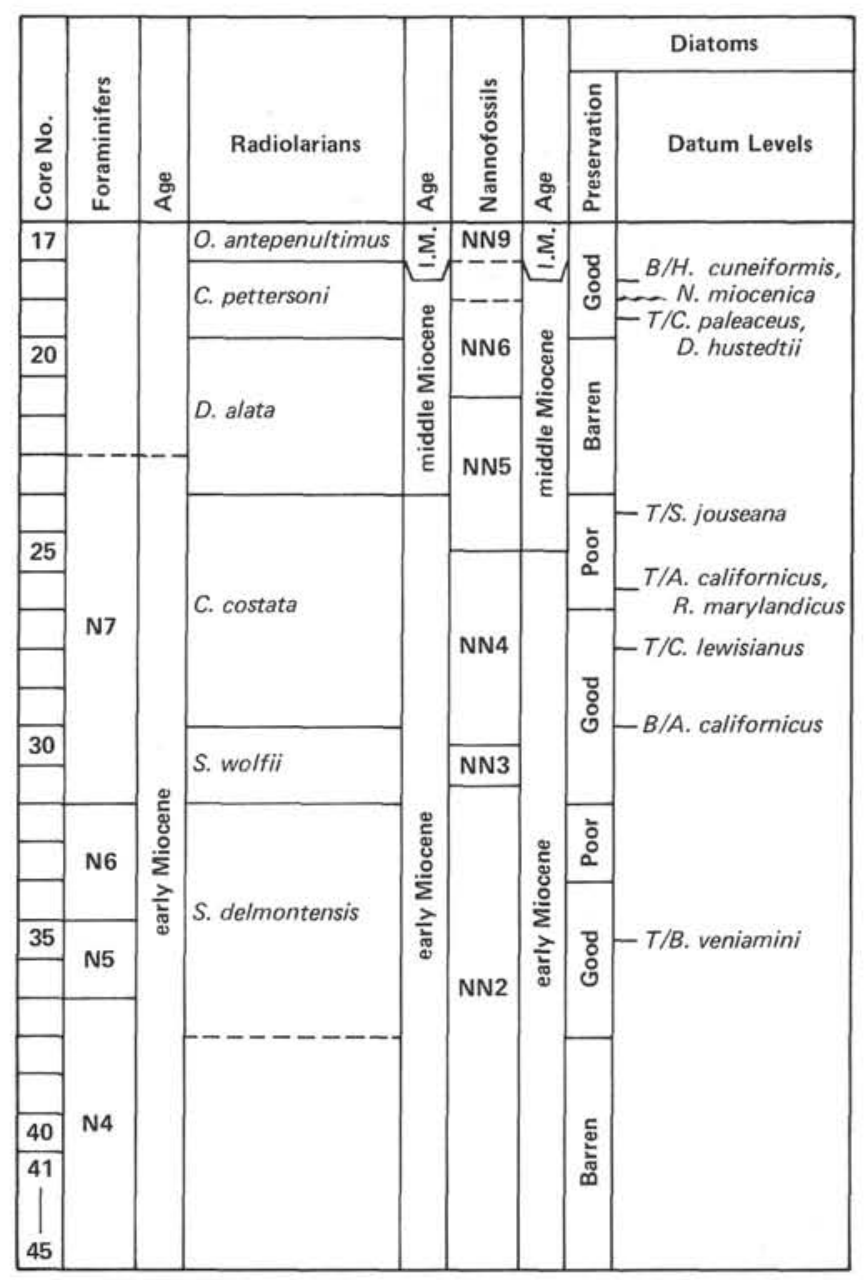

Figure 3. Diatom datum levels in the lower part of Hole 495 compared to other paleontology data. 
Table 3. Diatom occurrence chart and zonal and age assignments, Site 496.

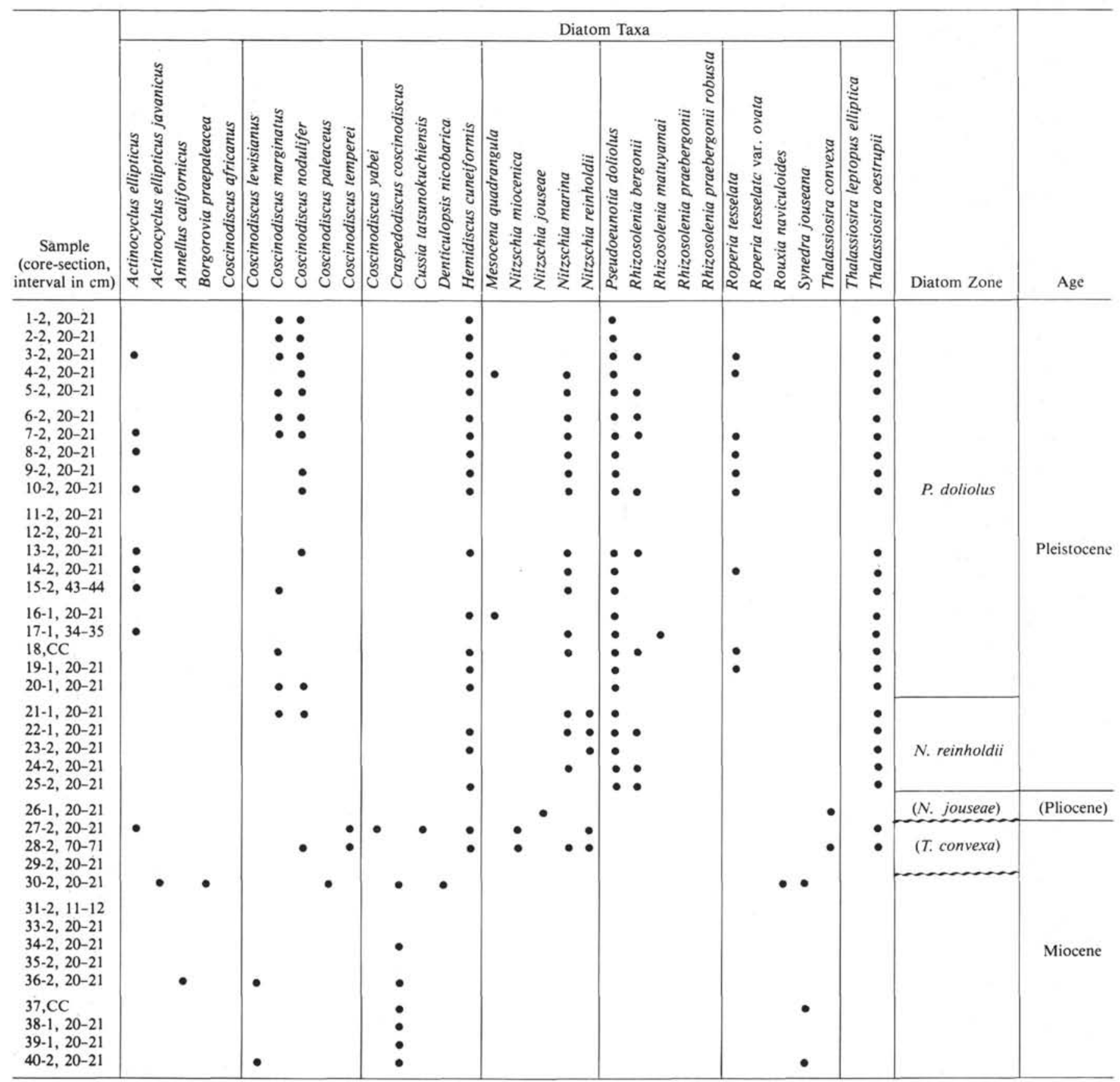

Note: $\bullet$ indicates presence in sample. 
Table 4. Diatom occurrence chart and zonal and age assignments for the upper part of Hole 497.

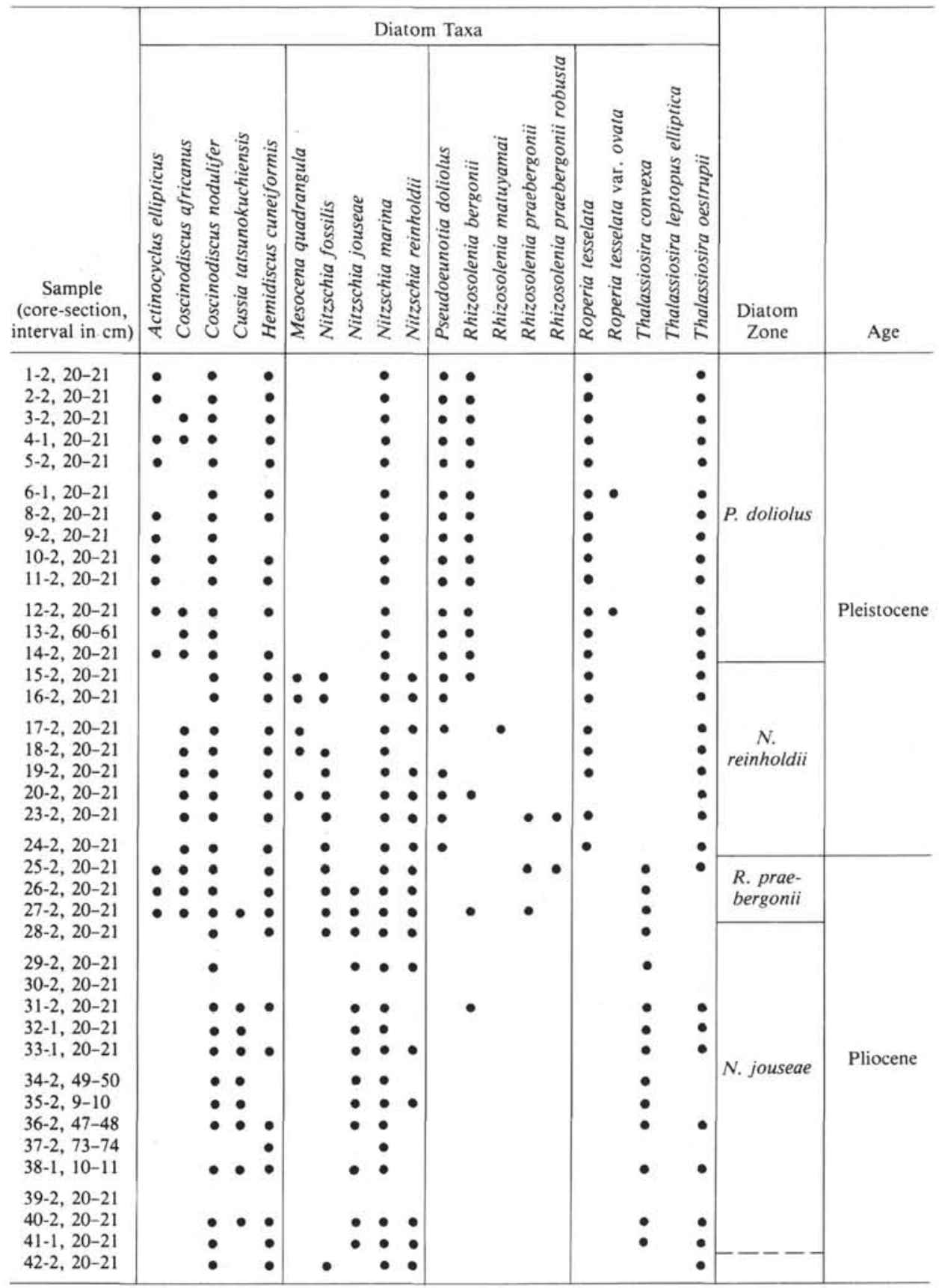

Note: $\bullet$ indicates presence in sample. 